\title{
Біологічні властивості та інтродукція представників роду Allium L у Кременецькому ботанічному саду
}

\section{Ірина Ковальчук, Ольга Берідзе, Ярослава Гетьман}

Кременецький ботанічний сад, м. Кременець, Україна

Адреса для листування: irina_skoroplas2017@ukr.net

Отримано: 28.04.20; прийнято до друку: 20.06.20; опубліковано: 02.09.20

\begin{abstract}
Резюме. Розширення асортименту квітниково-декоративних рослин для ландшафтного проектування сьогодні актуальне в усьому світі, зокрема і в Україні. Найбільш ефективні методи вирішення цього питання - інтродукція представників роду Allium L., вивчення їх еколого-біологічних особливостей, стійкості в культурі. Представники роду Allium L. здавна відомі своїми декоративними якостями та лікувальними властивостями. Колекція представників роду Allium Кременецького ботанічного саду нараховує 10 видів (Allium giganteum Regel, Allium schubertii Zucc., Allium karataviense Regel, Allium odorum L., Allium molly L., Allium nutans L., Allium scorodoprasum L., Allium sphaerocephalon L., Allium oreophilum C. A. Mey, Allium montanum F.W. Schmidt), гібрид (Allium azureum), 2 форми (Allium schoenoprasum cv 'blooming', Allium schoenoprasum cv 'snowcap') та 3 сорти (Allium 'Hair', Allium 'Powder purf', Allium 'Miami'). Інтродуценти послужили об'єктами досліджень з огляду на декоративні ознаки та доцільність їх використання в озелененні. Згідно з аналізом фенологічних спостережень фаза бутонізації наступила у всіх 15 видів, найперше була зафіксована 22 квітня в A. 'Powder purf', 26 квітня A. schoenoprasum cv 'blooming', A. schoenoprasum cv 'snowcap', A. karataviense, найпізніше 8 липня A. odorum, A. nutans, A. montanum. Найперше зацвіла A. 'Powder purf', A. karataviense, A. schoenoprasum cv 'snowcap', A. giganteum - 13 травня, найпізніше зацвіли A. nutans, A. odorum - 5 серпня. Найдовша фаза цвітіння відзначена у видів: A. sphaerocephalon, Allium 'Hair' - 46 днів, найкоротша фаза цвітіння в A. molly (13 днів). Дані про особливості сезонного циклу росту і розвитку, строки цвітіння мають практичне значення для озеленення при створенні квітникових композицій.
\end{abstract}

Ключові слова: інтродукція; Кременецький ботанічний сад; Allium; мезофіт; ксерофіт.

\section{Biological Properties and Introduction of Allium L General Representatives in the Kremenets Botanical Garden}

\section{Iryna Kovalchuk, Olha Beridze, Yaroslava Hetman}

Kremenets Botanical Garden, Kremenets, Ukraine

Address for correspondence: irina_skoroplas2017@ukr.net

\begin{abstract}
Expanding the range of flower and ornamental plants for landscape design is relevant today all over the world, including in Ukraine. The most effective methods of solving this question - the introduction of representatives of the genus Allium L., the study of their ecological and biological characteristics, sustainability in culture. Representatives of the genus Allium L. have long been known for their decorative qualities and medicinal properties. The collection of representatives of the genus Allium of the Kremenets Botanical Garden includes 10 species (Allium giganteum Regel, Allium schubertii Zucc., Allium karataviense Regel, Allium odorum L., Allium molly L., Allium nutans L., Allium scorodoprasum L., Allium sphaerocephalon L., Allium oreophilum C. A. Mey, Allium montanum F.W. Schmidt), hybrid (Allium azureum), 2 forms (Allium schoenoprasum cv 'blooming', Allium schoenoprasum $c v$ 'snowcap') and 3 varieties (Allium 'Hair', Allium 'Powder purf', Allium 'Miami'). Introducers have served as objects of research for decorative features and the
\end{abstract}


expediency of their use in landscaping. According to the analysis of phenological observations, the budding phase occurred in all 15 species, first recorded on April 22 in A. 'Powder purf', April 26 - A. schoenoprasum cv 'blooming', A. schoenoprasum cv 'snowcap', A. karataviense, no later than 8 July - A. odorum, A. nutans, A. montanum. First blossomed A. 'Powder purf', A. karataviense, A. schoenoprasum cv 'snowcap', A. giganteum - May 13, and later blossomed A. nutans, A. odorum - August 5. The longest flowering phase is noted in species: A. sphaerocephalon, Allium 'Hair' - 46 days, the shortest flowering phase in A. molly (13 days). Data on the peculiarities of the seasonal cycle of growth and development, timing of flowering are of practical importance for landscaping when creating flower arrangements.

Keywords: introduction; Kremenets Botanical Garden; Allium; mesophyte; xerophyte.

\section{ВСТУП}

Одним із шляхів вирішення проблеми збіднення флори Землі, внаслідок технічного прогресу та збільшення населення планети, є збереження родового та видового різноманіття рослин методом інтродукції.

Чималу роль у захисті генофонду рослинного світу, раціональному використанні рослинних ресурсів відіграє наукова діяльність ботанічних садів, яка сприяє збагаченню асортименту рослин і впровадженню в зелене будівництво нових видів.

У Кременецькому ботанічному саду щорічно поповнюється колекція трав'янистих рослин новими видами та сортами. Одним із таких представників $€$ рід Allium L. Представники роду Allium L. здавна відомі своїми декоративними якостями та лікувальними властивостями. Численні літературні дані свідчать, що багато дикорослих видів цибуль за багатьма показниками не лише не поступаються, але й переважають культурні форми, містять цінний комплекс біологічно активних речовин (фітонциди, вітаміни, мікроелементи та ін.), завдяки чому можуть використовуватись у вигляді сировини для фармацевтичної промисловості [1-2].

Рід Allium належить до родини Alliaceae, охоплює 700 видів, які заселяють північну півкулю, Південно-західну й Середню Азію, узбережжя Середземномор'я та західну частину Північної Америки, де трапляються на галявинах у лісах та високогір'ї. Найбільшим різноманіттям видів цибуль вирізняється Середня Азія, де зростає близько 170 видів. Серед декоративних видів Allium відомо 80, 3 них 20 культивується у широкому масштабі [3-6].

\section{МАТЕРІАЛ І МЕТОДИКА ДОСЛІДЖЕННЯ}

Наукові дослідження проводили згідно із загальноприйнятими методиками. Початок i кінець фенофаз встановлювали відповідно до методики фенологічних спостережень у ботанічних садах [7]. Створення колекцій i вивчення їх проводили за методикою В. М. Билова та Р. А. Карпісонової [8-10]. Створення колекції цибуль у ботанічному саду було розпочато в 2017 році. Поповнення колекції відбувалося 3 метою вивчення біоморфологічних особливостей, декоративних якостей, особливостей розмноження та використання у сучасному озелененні.

\section{РЕЗУЛЬТАТИ ТА ЇХ ОБГОВОРЕННЯ}

Колекція КБС представників роду Allium нараховує 10 видів, 1 гібрид, 2 форми та 3 сорти. Інтродуценти послужили об’єктами досліджень 3 огляду на декоративні ознаки та доцільність їх використання в озелененні.

Allium giganteum Regel - цибуля велетенська (гігантська). Багаторічний веснянолітньозелений трав'янистий цибулинний полікарпік. Мезофіт. Його назва говорить про значні розміри, висота рослини в період цвітіння досягає 123 см. Цибулина яйцевидна, шкіряста, 3 темно-сірою лускою, 3-7 см в діаметрі. Стебло міцне, листки ременеподібні, яскраво-зеленого кольору, 3-4 см ширини, 38$46 \mathrm{~cm}$ довжини. Квітки світло-фіолетові, зірчастої форми, зібрані в густе кулеподібне суцвіття діаметром 6,5-9,0 см. Фаза бутонізації припадає на 26.04-20.05, цвітіння - 13.0513.06. Надзвичайно декоративний вид завдяки ефективним яскраво-зеленим листям i щільному суцвіттю. Добре зростає в міксбордерах, серед чагарників і дерев.

Allium schubertii Zucc. - цибуля Шуберта. Зростає на вапнякових грунтах у нижньому поясі гір. Багаторічний весняно-ранньолітньозелений трав'янистий цибулинний полікарпік $з$ літнім періодом спокою. Ксерофіт. Цибулина кулеподібна, 2,8-4,1 см в діаметрі, білого кольору, зі світло-сірою лускою. Висота рослини в період цвітіння $-27 \mathrm{~cm}$. Листки набагато довші ніж квітконіс, широкі, сизозелені, до $3 \mathrm{~cm}$ шириною. Квітконіс має дивовижну форму, що незмінно приверне до себе увагу - всі квітконіжки різні за довжиною і утворюють величезну зірку. Кількість квіток у суцвітті - 30-160 шт. Квітка білувато-рожевого 
Біологічні властивості та інтродукиія представників роду Alliuт L у Кременецькому ботанічному cady

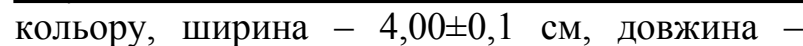
$1,2 \pm 0,06$ см. Фаза бутонізації припадає на 10.05-6.06, цвітіння - 27.05-27.06. При озелененні слід висаджувати на передньому плані альпінарію.

Allium karataviense Regel - цибуля каратавська. Багаторічний весняно-ранньолітньозелений трав'янистий цибулинний полікарпік з літнім періодом спокою. Ксерофіт. Цибулина кулеподібна, 4-7 см в діаметрі, білого кольору, зі світло-сірою лускою. Листків зазвичай 2, зрідка 3 , широкі, сизо-зелені, до 7,5 см шириною і 15-17,5 см довжиною. Висота рослини в період цвітіння - $16 \pm 3 \mathrm{~cm}$, зонтик кулеподібний, щільний, багатоквітковий (110 шт.). Квітка майже білого кольору, ширина

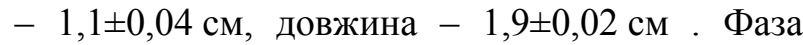
бутонізації припадає на 26.04-16.05, цвітіння 13.05-30.05. В озелененні слід враховувати невелику висоту рослини i висаджувати на передньому плані добре освітлених ділянках, у групових посадках i рокаріях. Можна використовувати в сухих букетах.

Allium odorum L. - цибуля запашна (ц. гілляста). Багаторічний весняно-літньоосінньозелений, короткокореневищноцибулинний полікарпік. Субксерофіт. Цибулини вузько-циліндрично-конічні, майже не виражені, 3 рудувато-бурими, сітчастими оболонками, прикріплені до горизонтального кореневища. Листки вузько-лінійні, генеративні пагони ребристі, зонтик напівкулястий багатоквітковий. Квітки зірчасті, білі, 3 фіолетовою жилкою на пелюстці, 1,2士0,02 cм довжини і 1,3 $\pm 0,02$ см ширини. Фаза бутонізації припадає на 8.07-5.08, цвітіння - 22.07-29.08. Добре росте на відкритих сонячних місцях.

Allium molly L. - цибуля золотава, Моля. Багаторічний весняно-ранньо-літньозелений травянистий цибулиний полікарпік 3 літнім періодом спокою. Мезофіт. Квітки зірчасті, жовті, зібрані в напівкулястий зонтик. Висота рослини 17-25 cм, на одній рослині утворюється 22-25 квіток, довжина квітки $1,1 \pm 0,1$ см, ширина - $1,6 \pm 0,08$ см. Листки ланцетні, сірувато-зелені, завдовжки 15,5 см і завширшки 1,5 см. Фаза бутонізації припадає на 13.05-27.05, цвітіння - 27.05-6.06. Добре зростає в напівтінистих вологих місцях. В озелененні найкраще застосовувати в рокаріях, міксбордерах, моногрупах.

Allium nutans L.- цибуля поникла, слизун. Багаторічний весняно-літньо-осінньозелений трав'янистий короткокореневищноцибулинний полікарпік. Субксерофіт. Цибулина одиночна, конічна, до 2 см, 3 бурувато-сірими плівчастими цільними оболонками. Стебло сплюснуте, до цвітіння верхівка поникла. Листки плоскі, ременеподібні, сизі. На одній рослині утворюється до 50 генетаривних пагонів. Зонтик кулястий, густий, багатоквітковий (107248 шт.). Квітки блідо-рожевого кольору $1,1 \pm 0,02 \mathrm{~cm}$ довжини i $0,7 \pm 0,02 \mathrm{~cm}$ ширини. Фаза бутонізації припадає на 8.07-8.08, цвітіння - 5.08-29.08. В озеленені використовувати на відкритих сонячних місцях, рокаріях, міксбордерах, моногрупами на тлі газону або чагарників.

Allium sphaerocephalon L. - цибуля круглоголова. Багаторічний весняно-ранньолітньозелений трав'янистий цибулинний полікарпік $з$ літнім періодом спокою. Ксерофіт. Цибулина яйцеподібна, 1,0-1,5 cм в діаметрі, бурого кольору, зі шкірястою, порепаною лускою. Висота рослини в період цвітіння $70 \pm 5$ см. Листки напівциліндричні, 1,3-1,6 см шириною і 12-18 см довжиною. Суцвіття щільний яйцевидний зонтик. Кількість квіток 180-215 шт. Квітка темно-пурпурова, ширина $0,4 \pm 0,02 \mathrm{~cm}$, довжина - $0,6 \pm 0,1$ см. Фаза бутонізації припадає на 23.05-10.06, цвітіння 6.06-18.07. При озеленювальних роботах розміщувати на задньому плані альпінарію, розаріїв, міксбордерах. Можна використовувати в сухих букетах.

Allium montanum F.W. Schmidt - цибуля гірська. Багаторічний весняно-літньоосінньозелений, короткокореневищноцибулинний полікарпік. Субксерофіт. Цибулини слабо потовщені, конічноциліндричні 1-1,5 см шириною. Листки лінійні, плоскі, без кіля, тупі. Генеративні пагони у верхній частині двогранні (на третій рік розвитку в кількості (12 шт.). Суцвіття напівкулясте, багатоквіткове (30-35 шт.), густе. Квітки зірчасті, рожеві або рожево-лілові, $0,9 \pm 0,02 \mathrm{~cm}$ довжини i $0,5 \pm 0,02 \mathrm{~cm}$ ширини. Фаза бутонізації припадає на 8.07-15.08, цвітіння - 29.07-15.08. В озелененні використовувати на відкритих сонячних місцях, в рокаріях, міксбордерах, моногрупами.

Allium schoenoprasum (cv 'blooming', 'snowcap') - цибуля скорода. Багаторічний весняно-літньо-осінньозелений трав' янистий короткокореневищно-цибулинний полікарпік. Мезофіт. Цибулини по одній або декілька прикріплені до горизонтального кореневища, довгасто-яйцевидні $0,5-1,0$ cм в діаметрі, 3 бурими, майже шкірястими оболонками. Листки циліндричні, порожнисті, стебло товстувате, зонтик пучкувато-напівкулястий, 
густий. Квітки вузько-дзвоникові, блискучі, рожево-фіолетові, $1,1 \pm 0,02 \mathrm{~cm}$ довжини i $0,9 \pm 0,02$ см ширини. Фаза бутонізації - 26.046.06, цвітіння - 20.05-13.06. У декоративному садівництві використовувати як бордюрну рослину, для обсадки доріжок, прикрашання газонів. Висаджувати моногрупами і в рокаріях. Allium 'Hair' (Allium sphaerocephalon 'Hair') - багаторічна трав'яниста рослина висотою $80 \pm 15$ см. Алліум круглоголовий, або барабанні палички, або алліум Сфероцефалум - це все назва однієї рослини. Його бутони підносяться на вершині $40 \pm 8$ - сантиметрових квітконосних стеблах. Вони міняють своє забарвлення від рожево-білого кольору до рожевого до середини травня. Суцвіття розміром до 2,8 см в діаметрі. Листя дудчасті, зеленого кольору. Фаза бутонізації припадає на 20.05-10.06, цвітіння - 6.06-18.07. Ця рослина віддає перевагу великій кількості сонця і родючому грунту. Може рости і в напівтіні. Підходить для кам'янистих садів i створення бордюрів, висаджують у групових посадках.

Allium oreophilum С. А. Меу - цибуля Островського. Багаторічний весняно-ранньолітньозелений трав'янистий цибулинний полікарпік з літнім періодом спокою. Мезофіт. Цибулина яйцевидна, світла, 3 плівчастим покриттям: діаметр - 1,25 $\pm 0,9$ см; висота $1,5 \pm 0,5$ см; маса - 1,4 $\pm 0,3$ г. Квітки зірчасті, пурпурово-рожеві, зібрані в багатоквіткові напівкулясті суцвіття. Морфометричні показники: висота рослини - $18 \pm 2 \mathrm{~cm}$, кількість

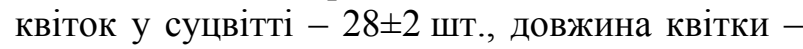
$1,1 \pm 0,1$ см, ширина - $1,6 \pm 0,08$ см. Фаза бутонізації припадає на 20.05-6.06, цвітіння 3.06-27.06. Використовувати в квітниках на передньому плані, для прикрашення газонів i лужків.

Allium 'Powder purf' - багаторічний весняноранньо-літньозелений трав'янистий цибулинний полікарпік 3 літнім періодом спокою. Ксерофіт. Цибулина яйцевидна, світла, 3 плівчастим покриттям: діаметр - 1,25 $\pm 0,9$ см;

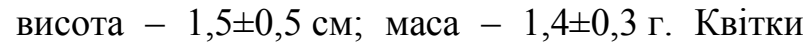
зірчасті, фіолетові, зібрані в багатоквіткові зонтичне суцвіття. Морфометричні показники:

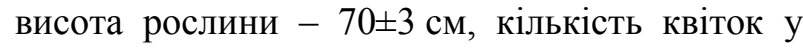

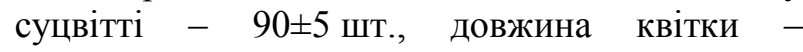
$1,2 \pm 0,1$ см, ширина - 1,5 $\pm 0,08$ см. Фаза бутонізації - 22.04-27.05, цвітіння - 13.05-6.06. $\mathrm{У}$ декоративному садівництві використовувати як бордюрну рослину, для обсадки доріжок, прикрашання газонів. Висаджувати моногрупами і в рокаріях.
Allium Miami - цибуля Маямі. Багаторічний весняно-літньозелений трав'янистий цибулинний полікарпік. Ксерофіт. Цибулина яйцевидна, шкіряста, 3 темно-сірою лускою, 2$3 \mathrm{~cm}$ в діаметрі. Висота рослини в період цвітіння досягає $60 \pm 5$ м. Стебло міцне, листки ланцетні, яскраво-зеленого кольору, 3-3,5 см ширини, 20-26 см довжини. Квітки фіолетовопурпурові, зірчастої форми, зібрані в зонтичне суцвіття діаметром 5-10 см. Фаза бутонізації припадає на 13.05-30.05, цвітіння - 23.0517.06. В озелененні використовувати на відкритих сонячних місцях, в рокаріях, міксбордерах, моногрупами на тлі газону або чагарників.

Allium scorodoprasum L. - цибуля часникова (рокамболь, єгипетський, іспанський часник). Багаторічний весняно-ранньо-літньозелений трав'янистий цибулинний полікарпік 3 літнім періодом спокою. Мезофіт. Цибулина яйцевидна, світла, 3 плівчастим покриттям: діаметр - 1,2 $\pm 0,9$ м; висота $-1,6 \pm 0,5$ см; маса $1,6 \pm 0,3$ г. Квітки дзвоникоподібної форми, бузкові, зібрані в кулясте суцвіття. Морфометричні показники: висота рослини $80 \pm 5$ см, кількість квіток у суцвітті - 80 шт., довжина квітки - $1,2 \pm 0,1 \mathrm{~cm}$, ширина $1,2 \pm 0,08$ см. Фаза бутонізації припадає - 20.0510.06, цвітіння - 10.06-15.07. У декоративному садівництві висаджують моно групами.

Allium azureum - цибуля Азуреум. Багаторічний весняно-літньозелений трав'янистий цибулинний полікарпік. Ксерофіт. Цибулина яйцевидна, шкіряста, 3 темно-сірою лускою, 2-3 см в діаметрі. Висота рослини в період цвітіння досягає $20 \pm 5$ см. Стебло міцне, листки ланцетні, сизо-зеленого кольору, 3-3,5 см ширини, 20-26 см довжини. Квітки голубі, зірчастої форми, зібрані в зонтичне суцвіття діаметром 6-8 см. Фаза бутонізації припадає на 10.05-1.06, цвітіння 15.05-12.06. В озелененні використовувати на відкритих сонячних місцях, в рокаріях, міксбордерах, моногрупами на тлі газону або чагарників.

\section{ВИСНОВКИ}

Таким чином колекція представників роду Allium створена для ознайомлення відвідувачів саду 3 видовим та сортовим різноманіттям цибуль флори України. Дані про особливості сезонного циклу росту i розвитку, строки цвітіння мають практичне значення для озеленення при створенні квітникових композицій. Групуючи види та сорти за 
Біологічні властивості та інтродукиія представників роду Alliuт L у Кременецькому ботанічному cady

термінами початку й кінця цвітіння, відзначили, що за часом зацвітання переважає група пізньовесняні (53,3\%), за тривалістю цвітіння - середньоквітучі (66,7\%). Отже, різноманітність цибуль дозволяє підібрати їх так, щоб створити сад безперервного цвітіння 3 включенням цього роду в поєднанні 3 іншими видами.

\section{ЛITEPАТУРА}

1. Кокарева, В. А. Декоративные луки; Армада-пресс: Москва, 2001; 32 с.

2. Рубановська, Н. В. Рід Allium L. у флорі Західного Поділля. Дисертація канд. біол. наук: 03.00.05. Київ, 2017; 240 с.

3. Веденский, А. И.; Гончаров, Н. Ф.; Горшкова, С. Г. Лук - Allium L. Флора СССР. Изд-во АН СССР: Ленинград, 1935; Т. 4, с 112-280.
4. Казакова, А. А.; Жуковский, П. М.; Коровина, О. Н. Культурная флора СССР. Лук. Колос: Ленинград, 1978; Т. 10, 264 с.

5. Омельчук, Т.Я. Нові види роду цибуля (Allium L.) у флорі України. Укр. ботан. журн. 1962, 19, 2, с 19-29.

6. Филимонова, 3. Н. Морфология луковицы некоторых видов рода Allium L. Узб. биол. журн. 1959, 4. с 20-31.

7. Методика фенологических наблюдений в ботанических садах СССР. Москва, 1975; 27 с.

8. Былов, В. Н.; Карписонова, Р. А. Принципы создания и изучения коллекции малораспространенных декоративных многолетников. Бюл. Гл. бот. сада. 1978, Вып. 107.

9. Карписонова, Р. А. Оценка успешности интродукции многолетников по данным визуальных наблюдений. Тезисы докладов VI Делегатского съезда ВБО. Львов, 1978.

10. Петренко, 3. А. Методи культивування видів роду Allium L. в умовах посушливого півдня України. Асканія-Нова, 2015; с 52. 